\title{
Crustal delimitation in the Brazilian Equatorial Margin
}

Juliana de Carvalho (Faculdade de Oceanografia -Universidade do Estado do Rio de Janeiro), Marcelo Sperle,(Faculdade de Oceanografia -Universidade do Estado do Rio de Janeiro)

Copyright 2019, SBGf - Sociedade Brasileira de Geofísica

This paper was prepared for presentation during the $16^{\text {th }}$ International Congress of the Brazilian Geophysical Society held in Rio de Janeiro, Brazil, 19-22 August 2019.

Contents of this paper were reviewed by the Technical Committee of the $16^{\text {th }}$ International Congress of the Brazilian Geophysical Society and do not necessarily represent any position of the SBGf, its officers or members. Electronic reproduction or storage of any part of this paper for commercial purposes without the written consen of the Brazilian Geophysical Society is prohibited.

\section{Abstract}

The present work aims to contribute with the debate about crustal boundary delimitation in Brazilian equatorial margin and consequently the definition of the distal boundary of an area considered as the new exploratory frontier of oil and gas. This work used two geophysical transects form the LEPLAC Project, located in the Pará-Maranhão Basin. After the seismic interpretation the tectonophisycs modeling was made relating the seismic data with gravimetric free-air data. The results, close to the Amazonas Fan and Ceará Rise in especial, showed discordant with the major part of the published works.. This may implies a new exploration frontier for oil and gas in the equatorial margin.

Introduction

The boundary between the continental and oceanic crust on a divergent-transcorrent mixed continental margin is complex, due the large thickness of the sedimentary package and the different tectono-magmatic processes associated to your genesis and evolution (Mascle et al., 1987). Because of this, determine the crustal boundary require a geophysics methods union, in this work the junction of the potential methods (gravimetry and magnetometry) and acoustic method (sismoestratigraphy) for the creation of a tecnophysical model.

The Focus of these studies in Brazil was concentrated on Southeast Margin, in the Santos, Espírito Santo and Campos Basins. However, recently the ANP ( National Oil and Gas Agency) is auctioning blocks on Brazilian Equatorial Margin, due to discovery of hydrocarbons on the Africa west coast; and how the both margins presented an analogue evolution there is a possibility those resources be present on the brazilian margin.

This Project extends from the Amapa to the Rio Grande do Norte, encompassing all Brazilian Equatorial Margin and counts with 10 lines (Figure 1) of the LEPLAC Project (Brazilian Platform Survey Project) arranged along the margin, for this work were selected two lines ( 4 and 5 - Figure 1) located in the Prará-Maranhão Baasin. Based on tectonophysical modeling was made a map with the crustal boundary indicated, aiming to contribute to subsequent demarcation of new exploratory frontiers on this margin.

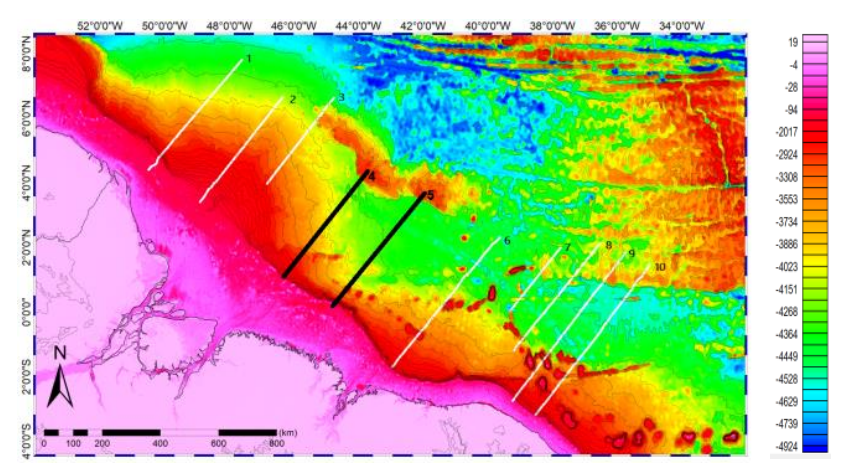

Figure 1: Bathymetric map of the Brazilian Equatorial Margin, with the 10 lines of the project indicates and the lines 4 and 5 highlighted in black.

Method

The used data come from the first phase of the LEPLAC Project, ceded by Brazilian Navy. The data are of seismic profiles, magnetometry and gravimetry, and were acquired by ship, simultaneously.

The selected lines were pre-analyzed and the gravimetry (Free-air) and magnetometry were used on the qualitative form and related with the seismic profile for better line understanding and a better model making and also used to find the anomalies witch indicate the crustal boundary, G Anomaly in magnetometry and Edge Effect in gravimetry.

The seismic interpretation was made utilizing the DIDGER 3 sofware, where the main horizons were identify using the sismoestratigraphy 
principles, like the difference between the velocities and densities. The interpreted profiles were related with the stratigraphic chart of the basin, which was proposed by Milani et al (2007), due similarities.

The crustal boundaries present a signature called Edge Effect Anomaly. This anomaly can be Single (corresponds to a sediment filling of a strong continental crust that confines the strong oceanic crust) (long wavelength and high amplitude) associated to margins with high stiffness, and Double (short wavelength and low amplitude) associated to margins with low stiffness (Watts and Marr, (1995)). There is two types of double Edge Effect, the Onshore Dipping Double (corresponds to a sediment filling of a weak continental crust that confines the strong oceanic crust) an d Offshore Dipping Double (corresponds to a weak continental crust that confines the weak oceanic crust).

The modeling was done in the GM-SYS software, GOSOFT, which is based on the solution of Tawani's line integral, which consists of the approximation of polygons of irregular bases, to creation of two-dimensional models, being possible to calculate its area to obtain the mass and the density of the bodies (Talwani,(1959)). Seismic horizons and the gravity anomalies were inserted and these were related with the density values proposed by Telford et al. (1993), Sperle and Sichel, (2004) and Watts et al. (2009), and the velocity proposed by Mooney, Prodehl and Pavlenkova, (2002), and the values were selected according to stratigraphic chart proposed by Milani et al (2007).

Results

The selected lines to be analyzed and modeled in this work were 4 and 5 (Figure 1), after an analysis of the all lines, they were selected for presenting a better quality and respond better to the purpose of this work, which is the crustal delimitation. These lines are found in Pará-Maranhão Basin and they have unique characteristics.

Line 4 extends from the break of the continental shelf to the Ceará Rise., with approximately $464 \mathrm{~km}$ long. It presents an extensive sedimentary package, in seismic profile is possible to observe 3 big horizons, being they, the top of the crystalline basement, the seabed and two others classified as sandstone and shale.

The anomalies pre-analysis indicated that the Anomalies $\mathbf{G}$ and Edge Effect, therefore, the crustal boundary would be between $130-150 \mathrm{~km}$ from the break of the continental shelf, approximately. The
Edge Effect Anomaly, of this line, was classified as low stiffness (double, Onshore Dipping double), according Watts and Marr, (1995)).

The modeling (Figure 2) of this line showed that the crustal boundary is approximately $150 \mathrm{~km}$ from the continental shelf break, as indicated by preanalysis; the Ceará Rise $\left(2,7 \mathrm{~g} / \mathrm{cm}^{3}\right)$ has a different density of the oceanic crust $\left(2.85 \mathrm{~g} / \mathrm{cm}^{3}\right)$, showing that it was formed in a distinct event from the oceanic crust formation.; and below the Ceará Rise there is a crustal thickening, what is expected for a LIP (Large Igneous Province).

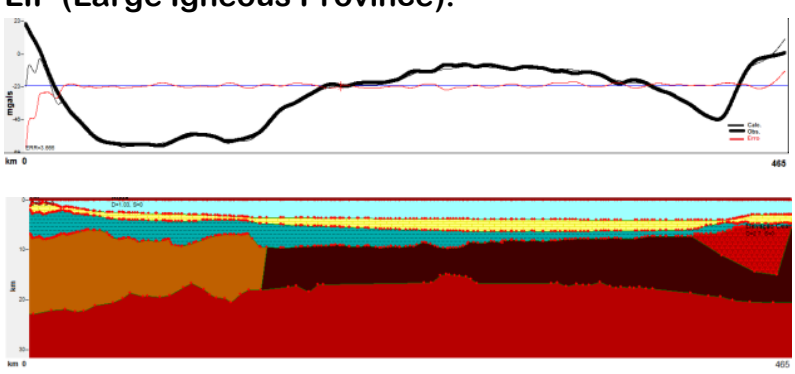

\begin{tabular}{|l|}
\hline Mantle \\
Oceanic Crust \\
Ceará Rise \\
Sandstone \\
Shale \\
Water \\
-Observed Free-air Anomaly \\
- Calculated gravimt. anomaly \\
\hline
\end{tabular}

Figure 2: Model of line 4, showing the crustal boundary in approximately $150 \mathrm{~km}$ after the continental shelf break. The Ceará Rise as a distinct body and the crustal thickening.

Such as line 4 , the Line 5 also extends form the break of continental shelf to Ceará Rise., with approximately $507 \mathrm{~km}$ long, however, this line presents a structural high right after the slope. The structural high origin can be connected with the Gurupi Guyot or Gurupi structural high origin, which originated from an active fault (Zanoto e Szatmari, (1987)). In the seismic profile we can identify the horizons, seabed, the crystalline basement and others two classified as sandstone and shale, as line 4.

In pre-analysis is possible to notice the structural high clearly, and the possible anomalies $\mathbf{G}$ and Edge Effect right after it, in approximately 150 $\mathrm{km}$ from the break of continental shelf. Due the structural high presence wasn't possible to classify the gravity anomaly as Watts and Marr, (1985).

However, the modeling (Figure 3 ) of this line indicated that the crustal boundary is found, in approximately, $50 \mathrm{~km}$ after the break of continental shelf, this boundary so close to the slope may be due to the position of the margin as to the continent's 
(Africa and south America) separation. The boundary, therefore, is before the structural high, which already is found in oceanic crust, probably formed together with the Gurupi Guyot through an active fault. It is also possible to observe the crustal thickening promoted by Ceará Rise.
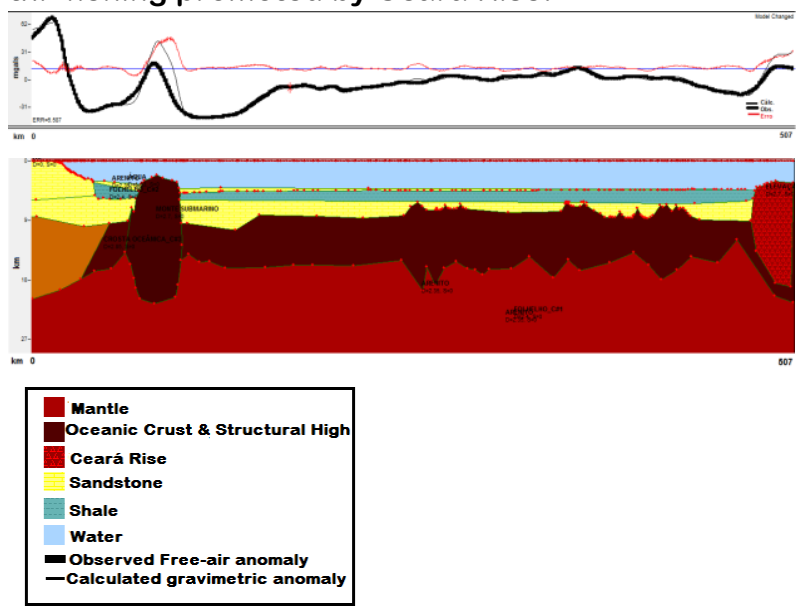

Figure 3: Model of line 5, showing the crustal boundary in approximately $50 \mathrm{~km}$ after the continental shelf break. The Structural high is quite evident. The Ceará Rise shows as a distinct body and the crustal thickening.

Using previous works of crustal delimitation in this region, and making a comparison between the proposed boundaries, is possible to observe that the boundaries found in this work correspond with the boundaries proposed by Santos, (2013) and is very distant from those proposed by Moulin, (2010), as is

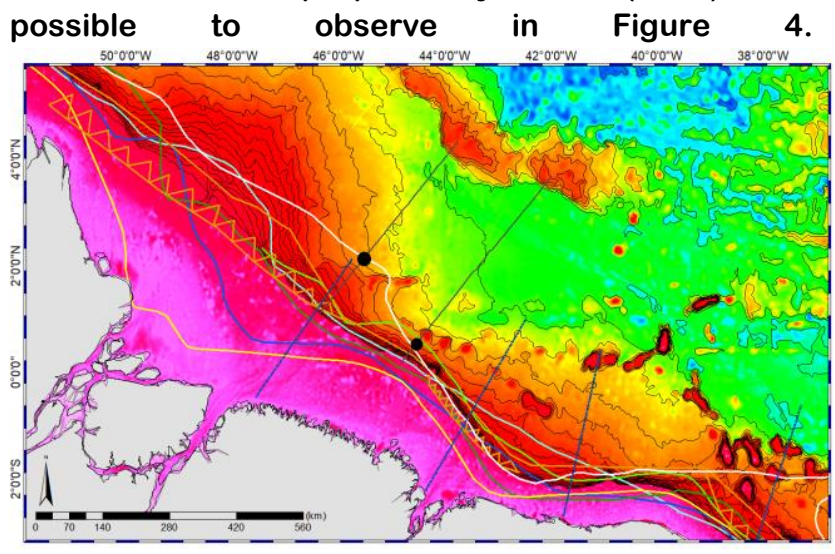

$$
\begin{aligned}
& \text { Seton et al., } 2012 \\
& \text { cOB Davison, } 2006 \\
& \text { сOB Santos, } 2013 \\
& \text { COB Nóbrega II, } 2011 \\
& \text { сОB Moulin, } 2010 \\
& \text { СОB Torvic, } 2009 \\
& \text { сOB Milani and Thomas Filho, } \\
& 2000
\end{aligned}
$$

Figure 4: Map with the comparison of crustal boundaries in the Brazilian equatorial margin. The blue lines are the divisions of the margin basins; the black lines are the lines modeled lines in this work with the respective boundaries indicated on a black point. his map has the isolines spaced every $250 \mathrm{~m}$. Works used in comparison Seton et al,(2012); Davison, (2006); Santos (2013); Nobrega II (2011); Moulin, (2010); Torvic (2009); Milani e Thomas Filho, (2000). Source: Santos, (in preparation).

\section{Conclusions}

The analysis of the abovementioned results resulted in the following conclusions:

- The modeling confirmed that the Brazilian Equatorial Margin presents a complex structures due to its multiphase evolution and the Ceará Rise, as a LIP, really promote a crustal thickening;

- The position in which the lines were acquired showed that the position of the margin during the separation influences the position of the boundaries, even in very close places, as shown by the lines 4 and 5 ;

- The gravimetric modeling proved to be satisfactory while the magnetometry was much complex and with a variety of parameters that would compromise the accuracy of the method;

- In Line 5 modeling, was possible to observe than in the structural high the calculated anomaly did not present a good fit, this is probably due the fact of this feature is of three-dimensional form and the model is two-dimensional;

- This work can contribute to the debate to define new exploratory frontiers in the Pará-Maranhão Basin, using a more local approach than the most of the available works.

\section{Acknowledgments}

We are gratefull to LEPLAC Team (Brazilian Navy) for sharing the data.

To Fundação de Amparo à Pesquisa do Estado do Rio de Janeiro - FAPERJ for the fellowship, To Conselho Nacional de Desenvolvimento Científico e Tecnológico (CNPq) for the financial support.

And to Faculdade de Oceanografia, Universidade do estado do Rio de Janeiro. 
MASCLE, J.; BASILE, C.; PONTOISE, B. 1987. The Cote D'Ivoire Ghana Transform Margin: An Example of an Ocean-Continent Transform Boundary. Rifted Ocean-Continent Boundaries, 1995. p. 327-339.

MILANI, E. J.; et al. Bacias sedimentares brasileirasCartas Estratigráficas. Boletim de Geociências da Petrobras, Rio de Janeiro, 2007. v. 15, n. 2, p. 183205.

MOONEY, W. D; PRODEHL, C.; PAVLENKOVA, N. Seismic velocity structure of the continental lithosphere from controlled source data. IN: INTERNATIONAL HANDBOOK OF EARTHQUAKE AND ENGINEERING SEISMOLOGY, Int'I Assoc. Seismol. \& Phys. Earth's Interior, Committee on Education, 2002. V. 81 A. ISSBN: 0-12-440652-1

Santos, M.V.M. (Em preparação) 0 papel das Cadeias Vulcânicas na compartimentação e nos processos deposicionais da margem equatorial brasileira e bacia oceânica. Tese de doutorado Faculdade de Oceanografia, UERJ

SANTOS, M.V.M. A Cadeia Norte Brasileira: características e feições determinadas através da análise de dados sísmicos e potenciais. Dissertação de mestrado, UFF, 172p. 2013

SPERLE, M.; SICHEL, S. O Interior da Terra. In: BAPTISTA NETO, J. A.; PONZI, V.R.A.; SICHEL, S. E. Introdução à geologia marinha. 2004. Rio de Janeiro, Ed. Interciência, p. 11-30.

TALWANI, M.; WORZEL, J. L.; LANDISMAN, M. Rapid Gravity Computations for Two-Dimensional Bodies with Application to the Mendocino Submarine Fracture Zone. Journal of Geophysical Research, 1959. v. 64, no 1, p 49-59.

TELFORD, W. M.; GELDART, L. P.; SHERIFF, R.E. Applied Geophysics. Estados Unidos da América, Ed. Cambribdge University, $2^{a}$ ed.,1990.

WATTS, A. B.; et al. Seismic structure, gravity anomalies, and flexure of the Amazon continental margin, NE Brazil. Journal of Geophysical Research, v. 114, p 1-23. 2009. doi:10.1029/2008JB006259

WATTS, A.B.; MARR,C. Gravity anomalies and the thermal and mechanical structure of rifted continental margins. Rifted Ocean-Continent Boundarie, 1995. SPRINGER, ISBN 978-94-0110043-4

ZANOTTO, O., SZATMARI, P. Mecanismos de rifteamento da porção ocidental da margem norte brasileira, Bacia do Pará-Maranhão. Revista Brasileira de Geociências. Volume 17(2), Páfs. 189195, junho 1987. 